DPST -85-861

\title{
HYDROXIDE DEPLETION IN DILUTE SUPERNATES STORED IN WASTE TANKS (U)
}

by

D. T. Hobbs

Westinghouse Savannah River Co.

Savannah River Site

Aiken, South Carolina 29808

This is a technical report.

The information contained in this report was prepared in connection with work done under Contract No. DE-AC09-76SR00001 with the U.S. Department of Energy. By acceptance of this paper, the publisher and/or recipient acknowledges the U.S. Government's right to retain a nonexclusive, royalty-free license in and to any copyright covering this paper, along with the right to reproduce and to authorize others to reproduce all or part of the copyrighted paper. 
Hydroxide Depletion

Carbon Dioxide Radiolytic Decomposition Waste Tanks

$$
\text { to c. Nio. 1096!l }
$$

TECHNICAL DIVISION

SAVANNAH RIVER LABORATORY

MEMORANDUM
DPST-85-861

CC: J. K. Okeson, 773-A

W. R. Stevens, III, 773-A

R. M. Wallace, 773-A

G. W. Wilds, 773-A

J. T. Ratliff, 773-A

J. P. Howel1, 773-A

R. J. Ondrejcin, 773-A

J. W. Congdon, 773-A

E. L. Denham, 773-A

MSM File, 773-A

SRL Records (4), 773-A

October 10,1985

TO: M. A. EBRA, 773-A<smiles>[AlH2]</smiles>

FROM: D. T. HOBBS, 773-A

HYDROXIDE DEPLETION IN DILUTE SUPERNATES STORED IN WASTE TANKS

SUMMARY AND RECOMMENDATIONS

Free hydroxide ion in dilute supernates are depleted by reaction with atmospheric carbon dioxide to form bicarbonate and carbonate species and by reaction with acidic compounds formed by the radiolytic decomposition of tetraphenylborate salts. A model of the kinetics and thermodynamics of absorption of carbon dioxide in the waste tanks has been developed. Forecasts of the rate of hydroxide depletion and the requirements for sodium hydroxide to maintain technical standards have been made for the washed sludge and washed precipitate storage tanks. Hydroxide depletion is predicted to have a minimal impact on sludge processing operations. However, in-tank precipitation and downstream DWPF operations are predicted to be significantly affected by hydroxide depletion in Tank 49H. The installation of a carbon dioxide scrubber on Tank $49 \mathrm{H}$ may be justified in view of the decrease in alkali content and variation in the melter feed. 
The following actions are recommended:

1. WMT determine feasibility of installing a carbon dioxide scrubber on Tank $49 \mathrm{H}$.

2. WMT and SRL continue monitoring atmospheric and tank carbon dioxide levels and chemical composition of dilute supernates in Tanks $42 \mathrm{H}$ and $48 \mathrm{H}$ to verify model.

3. WMT conduct test authorization (Test Authorization No. 1099) on Tank $42 \mathrm{H}$ to allow the supernate to fall below technical standards in order to collect additional data on reaction kinetics and inhibitor levels for the model.

4. WMT and SRL investigate alternate methods of maintaining free hydroxide level above $\mathrm{pH} 12$ in washed precipitate storage tank.

\section{RESULTS AND DISCUSSION}

Two mechanisms for the depletion of free hydroxide in dilute supernates stored in waste tanks have been established. One mechanism is the absorption of atmospheric carbon dioxide which reacts with hydroxide ion to afford bicarbonate and carbonate species. This mechanism is universal to all waste tanks in which air is continuously passed to prevent the build-up of explosive gas mixtures. The other mechanism is the neutralization of hydroxide by acidic compounds generated by the radiolytic decomposition of oganic compounds. This mechanism has been identified by $D$. $D$. Walker of IWT as an important mechanism in the storage of radioactive tetraphenylborate saits (1).

A model of the waste tanks has been developed to predict the kinetics and thermodynamic equilibrium and non-equilibrum inhibitor levels for dilute supernates that will be stored in the waste tank farm (2). Associated with the waste tank is a gas phase (predominantly air), a liquid phase (consisting of a dilute aqueous solution of sodium salts of nitrate, nitrite, hydroxide, carbonate, sulfate, etc.), and a solid phase (comprised of metal oxides and hydroxides in washed sludge and TPB salts and $\mathrm{NaTi}_{2} \mathrm{O}_{5} \mathrm{H}$ solids in washed precipitate). Air is drawn into the tank and is in contact with the solution phase. Carbon dioxide in the air is absorbed by the solution and reacts instaneously with hydroxide ion to form bicarbonate and carbonate species. Equilibrium is reached when the partial pressure of carbon dioxide in the waste tank equals the partial pressure of carbon dioxide in the incoming air.

Forecasts of the rate of hydroxide depletion and the requirements for sodium hydroxide to maintain technical standards have been made for the washed sludge and washed precipitate storage tanks. The 
forecast are based on the tank model and the rate of hydroxide depletion observed by radiolysis. CPES (Rev. 90, Oct. 30, 1984) flowsheet concentrations, experimentally determined $\mathrm{CO}_{2}$ levels and mass transfer coefficients and current design operations procedures formed the bases for the calculations.

A two year supply of washed sludge will be stored in either tank $40 \mathrm{H}$ or tank 51H. Based on the model, the free hydroxide level in supernate is predicted to fall below technical standards (pHl2) shortly after 23 months. Thus the tank will be out of technical standards for no more than one month. Additional sodium hydroxide can be added to raise the free hydroxide level. The amount of sodium hydroxide will have a minimal impact on the alkali contact in the melter feed because of the small volume of washed sludge remaining at that time. Furthermore, recent experiments at SRL by A. F. Riechman and J. W. Congdon and actual experience with Tank $42 \mathrm{H}$ at $\mathrm{pH}$ values as low as 9.5 indicate a low potential for pitting corrosion of the waste tank containing washed sludge $(3-5)$. Thus additional sodium hydroxide may not be required. Because of the low impact on downstream processing and low tank corrosion potential, the installation of a $\mathrm{CO}_{2}$ scrubber on washed sludge storage tanks would not be recommended.

Washed precipitate will be stored in Tank $49 \mathrm{H}$ prior to transfer to the acid hydrolysis cell in the DWPF. During the initial two years of in-tank precipitation as Tank $49 \mathrm{H}$ is filled, the free hydroxide level is predicted to fall below technical standards seven times. The addition of a sufficient quantity of sodium hydroxide to maintain technical standards during this time would result in a 50 \& increase in the sodium level in the supernate. During the next five years as slurry is added and removed from the tank, the free hydroxide level will fall below technical standards 3-4 times per year. Addition of sodium hydroxide in a sufficient quantity to maintain technical standards during this time period will increase the $\mathrm{Na}^{+}$content in the melter feed by 18-248. In addition to the large increase in $\mathrm{Na}^{+}$. content, the variability of the alkali level is also of concern. The $\mathrm{Na}^{+}$level will change no less than six times per year.

The installation of a carbon dioxide scrubber that would lower the carbon dioxide concentration to $100 \mathrm{ppm}$ would reduce the $\mathrm{Na}^{+}$ level in the melter feed by 408 . This reduction is produced by eliminating the sodium hydroxide additions made each year due to carbon dioxide absorption. In addition, the variation in $\mathrm{Na}^{+}$ content would also be reduced slightly. Final justification for the scrubber must consider installation and operating costs of the scrubber system, advantages (if any) of a 11-158 increase in the current flowsheet alkali content in the melter feed with a scrubber versus a 18-248 increase without a scrubber, and alternative methods for maintaining high inhibitor and low corrosion potentials. 
M. A. BRA

$-5-$

DP ST -85-861

October 10,1985

REFERENCES

1. D. D. Walker, Monthly Progress Report Waste Technology Group, June 1985 .

2. D. T. Hobbs and R. M. Wallace, "Hydroxide Depletion in Waste Storage Tanks by Reaction with Carbon Dioxide," DPST-85-846, to be issued.

3. A. F. Riechman, In-Tank Precipitation Corrosion Test Results, DPST-82-801, September 2, 1983 .

4. J. W. Congdon, Corrosion Tests in Syunthetic Washed sludge, DPST-85-853, October 16, 1985 .

5. A. F. Riechman, "In-Tank Processing: Inspection Results for Tanks $42 \mathrm{H}$ and $48 \mathrm{H}, " \mathrm{DPST}-85-471$, May 7, 1985 . 